Jakub Gortat

Łódź

\title{
NIEMCY JAKO OFIARY II WOJNY ŚWIATOWEJ W KINEMATOGRAFII XXI WIEKU
}

Autoprezentacja Niemców jako ofiar II wojny światowej nie jest w dyskursie tego kraju zjawiskiem nowym - można powiedzieć, iż istnieje w debacie publicznej oraz kulturze Niemiec właściwie już od momentu zakończenia wojny i doczekała się wielu opracowań badaczy zajmujących się tematyką polityki historycznej, pamięci kulturowej czy używając typowo niemieckiego określenia, obszarem „Vergangenheitsbewältigung”, czyli przezwyciężaniem narodowosocjalistycznej przeszłości, a nawet własnego terminu - Opfernarrative, co tłumacząc dosłownie oznacza narracje ofiar.

Analizując samo zjawisko kulturowe Opfernarrative można wyróżnić cztery zasadnicze typy narracji, które istnieją zarówno w literaturze jak i filmie niemieckim. Pierwszym obszarem narracji jest problematyka ucieczki i przymusowego wysiedlenia (w nomenklaturze naszego sąsiada określanej jako wypędzenia). W narracjach poświęconych tym wydarzeniom zazwyczaj opisywany jest trudny los ludności cywilnej, która zimą 1945 roku została zmuszona do opuszczenia swych ziem w obliczu postępującej ofensywy wojsk radzieckich. Drugim obszarem Opfernarrative są bombardowania miast niemieckich przez siły lotnicze aliantów zachodnich, przede wszystkim Drezna, trzecim masowe gwałty dokonywane przez żołnierzy sowieckich na Niemkach w ostatnich tygodniach wojny. Czwarty natomiast cierpienia żołnierzy niemieckich na froncie wschodnim lub w niewoli radzieckiej. Kwestia Opfernarrative jest, jak się okazuje, nadal aktualna i obecna w kulturze niemieckiej mimo faktu upłynięcia ponad sześciu dekad od zakończenia II wojny światowej. Aleida Assmann, wybitna badaczka pamięci kulturowej w Niemczech, w swojej pracy „Długi cień przeszłości” zauważa wyjątkowy boom Opfernarrative po roku 
1995, kiedy to obchodzono 50. rocznicę zakończenia II wojny światowej. Według Assmann, w przeciwieństwie do obchodów 40. rocznicy zakończenia wojny, kojarzonych głównie ze słynną mową prezydenta Richarda von Weizsäckera w Bundestagu 8 maja 1985 r., w trakcie obchodów rocznicy 50. znalazło się wiele tematów poświęconych właśnie cierpieniu niemieckiej ludności cywilnej. Kluczową datą w tym procesie był niewątpliwie rok 2002, nazwany przez Assmann momentem „pęknięcia tamy”; wówczas na niemieckim rynku wydawniczym ukazały się dwie bardzo istotne publikacje eksponujące niemieckie krzywdy.

Pierwszą z nich była kontrowersyjna książka pisarza i historyka badającego okres narodowego socjalizmu, Jörga Friedricha pod tytułem „Der Brand". Friedrich, który stał się sławny w latach 80. za sprawą swojej krytycznej rozprawy z zaniedbaniami denazyfikacji „Freispruch für die Nazi-Justiz", tym razem w swojej prawie 600-stronicowej pracy w sposób drobiazgowy i bardzo skrupulatny zaprezentował historię bombardowań jako środka militarnego w Europie w czasie II wojny światowej. Mimo iż autor rozpisywał się nad przeprowadzaniem bombardowań przez obie strony konfliktu (wspominając choćby o bombardowaniach Luftwaffe w Polsce w 1939 r. i Wielkiej Brytanii w roku następnym), przywołując także słowa czołowych niemieckich polityków tego okresu, ogień krytyki komentatorów skupił się właśnie na akcentowaniu przez Friedricha bombardowań miast niemieckich przez lotnictwo alianckie. "Der Brand” nie wzbudziłby z pewnością tak wielkich kontrowersji gdyby nie określony typ słownictwa użyty w kontekście zniszczeń niemieckich - otóż pisząc o piwnicach, w których ludność cywilna bombardowanych miast szukała schronienia, a w których w wyniku zaczadzenia odnalazła śmierć, Friedrich używa słowa "Gaskammer" (komory gazowe), same akcje bombardowania nazywa "masakrą cywili”, jedną z ich przyczyn "chęć wytępienia” („,Ausrottung”) ludności niemieckiej, a siły lotnicze „Einsatzgruppen”. Takie posunięcie było ewidentnym neosemantyzmem w dyskursie na temat sprawców i ofiar wojny - wobec Niemców użył bowiem Friedrich nazewnictwa typowego dla literatury holocaustu, natomiast $\mathrm{w}$ odniesieniu do aliantów nazw związanych z polityką III Rzeszy.

Drugą książką sięgającą do narracji ofiar, również wydaną w 2002 r., była nowela Günthera Grassa „Im Krebsgang” („Idąc rakiem”), w której autor konstruuje fabułę na kilku płaszczyznach czasowych, związując jedną klamrą losy trzech bohaterów - Wilhelma Gustloffa, działacza NSDAP w Szwajcarii, Davida Frankfurtera, Żyda, który go zamordował, oraz Antonina Marinesku, dowódcy u-boota radzieckiego, który zimą 1945 r. storpedował statek Gustloff przewożący ludność niemiecką z Prus Wschodnich. Ową klamrą kompozycyjną jest natomiast symboliczna data 30 stycznia oznaczająca po pierwsze datę dojścia Adolfa Hitlera do wła- 
dzy, po drugie datę urodzin Wilhelma Gustloffa i po trzecie datę zatopienia statku Gustloff. Wydarzenia te stanowią tło dla współczesnych losów rodziny narratora, a przede wszystkim jego syna, który zamieszczając na forum internetowym liczne antysemickie i rewizjonistyczne komentarze otwarcie dąży do konfrontacji ze swoim żydowskim interlokutorem. Grass chyba jako pierwszy pisarz zastosował mnogą narrację ofiar - w jego noweli głosy ofiar katastrofy Gustloffa są słyszalne do dziś wywołując nienawiść i gorzkie uczucie bólu.

Wyżej wymienione przykłady nie wyczerpują opisania nowości książkowych wykorzystujących niemiecką narrację ofiar. W ostatnich latach pojawiły się także liczne dzienniki i wspomnienia oraz autobiografie obfitujące w retrospekcje wojenne, jak choćby „Verbotene Trauer. Ende der deutschen Tabus"1 Klausa R. Röhla z roku 2002 czy "Am Beispiel meines Bruders"2 Uwe Timma z roku 2003. Popularne stają się najwyraźniej również wspomnienia byłych żołnierzy Wehrmachtu, które doczekały się także polskich edycji.

Podobną mnogość tytułów, w których objawia się niemiecka narracja ofiar, występuje we współczesnych produkcjach filmowych, zarówno dokumentalnych, jak i fabularnych. W przypadku tych pierwszych niewątpliwie dużą rolę $\mathrm{w}$ popularyzowaniu historii II wojny światowej odgrywają produkcje Guido Knoppa, w tym nadawany od dwunastu lat na antenie ZDF program Guido Knoppa "ZDF-History”, a także inne dokumentalne produkcje Knoppa, wśród których odnaleźć można m.in. programy poświęcone cierpieniom ludności niemieckiej ${ }^{3}$. Nie mniejsze zainteresowanie tematyka ta wzbudza wśród filmowców kręcących znaczące, pełnometrażowe produkcje fabularne, o których będzie mowa w dalszej części artykułu.

Jeżeli chodzi o motywy występujące w filmach nawiązujących do wojennej traumy Niemiec, jakie miały premierę po 2000 r., zauważyć można wyraźne podobieństwo kinematografii do literatury. Zauważyć można zatem te same główne toposy:

1. Masową ucieczkę ludności cywilnej z ziem wschodnich Rzeszy znajduje ona odzwierciedlenie przede wszystkim w takich obrazach jak

${ }^{1}$ K. R. Röhl, Verbotene Trauer. Ende der deutschen Tabus, Klaus Rainer. Verbotene Trauer - Ende der deutschen Tabus. München, 2002.

${ }^{2}$ U. Timm, Am Beispiel meines Bruders, Köln 2003.

${ }^{3}$ Można w tym miejscu wymienić m.in. serię filmów dokumentalnych Guido Knoppa „Die Gefangenen” z roku 2003 czy dokument fabularyzowany „Die Kinder der Flucht - Wolfkinder", w reżyserii Hansa-Christopha Blumenberga z 2006 r. również pod kierownictwem redakcyjnym Knoppa, który nb. można od kilku miesięcy oglądać w serwisie YouTube, http://www.youtube.com/watch?v=xk2kMA8-pMI [ostatni dostęp: 1.12.2012]. 
dwuczęściowa „Die Flucht” Kaia Wessela4, „Die Gustloff” Josepha Vilsmaiera ${ }^{5}$ czy mini serial „Sinking of Laconia”, brytyjsko-niemiecka koprodukcja Uwe Jansona 6 .

2. Alianckie bombardowania miast niemieckich - największą produkcją traktującą o tych wydarzeniach jest niewątpliwie "Dresden” Rolanda Suso Richtera ${ }^{7}$.

3. Gwałty dokonywane przez radzieckich żołnierzy na Niemkach ukazane w filmie „Anonyma - Eine Frau in Berlin” w reżyserii Maxa Färberböcka8.

Ponadto $\mathrm{w}$ filmie niemieckim dopatrzeć się można odniesień do wydarzeń w literaturze właściwie rzadko spotykanych, z tego względu można zaryzykować stwierdzenie, iż najnowsza kinematografia kreuje dwa nowe motywy z obszaru Opfernarrative. Są to:

4. Walka podejmowana przez chłopców próbujących udowodnić swoje bohaterstwo, którą podejmują w ostatnich dniach wojny, gdy klęska III Rzeszy jest nieunikniona - z ogólno dostępnych filmów wymienić można dwa: „Die Brücke” Wolfganga Panzera9 oraz niemiecko-ukraińsko-rosyjską koprodukcje „, 4 Tage im Mai" Achima von Borriesa ${ }^{10}$

5. Jednostkowi Niemcy, którzy nie zgadzają się z polityką NSDAP i w mniejszym bądź większym stopniu stawiają jej opór - są to oparte na biografiach tychże osób filmy takie jak "Sophie Scholl - die letzten Tage” Marca Rothemunda ${ }^{11}$ koncentrujący się na sześciu ostatnich dni życia młodej opozycjonistki i jej brata czy "John Rabe" Floriana Gallenberga ${ }^{12}$ opowiadający o działalności niemieckiego konsula w Nankinie, który przyczynił się do ocalenia wielu tysięcy Chińczyków w czasie masakry dokonywanej przez sojusznicze wojska Japonii albo właściwie nieznany w Polsce obraz Margarethe von Trotta pod tytułem „Rosenstraße” uka-

\footnotetext{
4 „Die Flucht”, polski tytuł „Ucieczka”, reżyseria: Kai Wessel, Niemcy 2007.

5 „Die Gustloff”, polski tytuł „Rejs ku śmierci”, reżyseria Joseph Vilsmaier, Niemcy 2008.

${ }^{6}$ "The Sinking of Laconia", reżyseria Uwe Janson, Niemcy-Wielka Brytania 2010.

7 „Dresden”, polski tytuł „Drezno”, reżyseria Roland Suso Richter, Niemcy 2006.

8 "Anonyma - Eine Frau in Berlin”, polski tytuł „Kobieta w Berlinie”, reżyseria Max Färberböck, Niemcy 2008.

9 "Die Brücke”, polski tytuł most, reżyseria Wolfgang Panzer, Niemcy 2008. Film stanowi remake wielokrotnie nagradzanego, antywojennego filmu z 1959 r. o tym samym tytule w reżyserii Bernharda Wicki'ego.

${ }^{10}$ „4 Tage im Mai”, brak polskiego tytułu, reżyseria Achim von Borries, NiemcyRosja-Ukraina, 2011.

11 "Sophie Scholl - die letzten Tage”, polski tytuł „Sophie Scholl - ostatnie dni", reżyseria Marc Rothenburg, Niemcy 2005.

12 "John Rabe", polski tytuł identyczny, reżyseria Florian Gallenberg, NiemcyFrancja-Chiny 2009.
} 
zujący pokojowe protesty kobiet niemieckich przeciwko deportacji ich żydowskich mężów w Berlinie w 1943 r. ${ }^{13}$

Osobno należy traktować jeden z najsłynniejszych obrazów kinematografii niemieckiej ostatnich lat, kontrowersyjny „Der Untergang” Olivera Hirchbiegela ${ }^{14}-\mathrm{w}$ tle fabuły namalowanych jest bowiem wiele obrazów chylącej się ku upadkowi Rzeszy, na pierwszym planie zaś obserwujemy natomiast słabego, schorowanego Führera, niepotrafiącego przyjąć do wiadomości nastającej rzeczywistości.

Wymienione wyżej tytuły niewątpliwie nie wyczerpują listy wszystkich produkcji niemieckich powstałych po 2000 r., w których odnajdziemy narrację ofiar. W niniejszym artykule niemożliwe jest ponadto omówienie wszystkich wspomnianych dzieł, dlatego główny nacisk w dalszej jego części będzie położony na trzy wielkie produkcje, które zachęciły rzesze widzów w Niemczech do odwiedzenia kin i które spotkały się z szerokim spektrum recenzji i dyskusji.

Pierwszym z nich jest „Dresden” Rolanda Suso Richtera opowiadający historię młodej pielęgniarki, Anny, która pracuje w jednym z drezdeńskich szpitali. Jej praca nie należy do najłatwiejszych - jest środek zimy 1945 roku, do szpitala przybywają liczni chorzy i ranni, kończą się lekarstwa i środki znieczulające. W tym samym szpitalu pracuje narzeczony Anny, Alexander, lekarz, wobec którego bohaterka odczuwa coraz większą rezerwę. Tymczasem ojciec Anny, przeczuwając, że Rzesza nie ma szans na zwycięstwo, w ścisłej tajemnicy planuje ucieczkę z całą rodziną do Szwajcarii, prowadząc niezupełnie moralne i legalne interesy z pewnym oficerem Wehrmachtu. Momentem przełomowym w życiu wszystkich bohaterów, choć Anny w pierwszej kolejności, jest zestrzelenie brytyjskiego lotnika, Roberta Newmana, przez Luftwaffe, który w ostatniej chwili ratuje życie katapultując się z płonącego samolotu. Rannego Roberta odnajduje pewnego dnia w szpitalnej piwnicy Anna, co radykalnie zmienia jej życiowe decyzje. Decyduje się ona udzielić Brytyjczykowi schronienia, ryzykując przy tym bardzo wiele. Znajomość przeradza się w miłosne uczucie, które stawia Annę przed trudnym dylematem. Ostatecznie miłosne rozterki schodzą na dalszy plan fabuły w chwili rozpoczęcia bombardowania miasta przez lotnictwo RAF.

„Dresden” było drugą wielką produkcją w karierze filmowej Rolanda Suso Richtera. Wcześniej w roku 2001, pochodzący z Marburga reżyser zasłynął opartym na faktach filmem „Der Tunnel”15, opowiadającym

\footnotetext{
13 "Rosenstraße”, brak polskiego tytułu, reżyseria Margarethe von Trotta, Niemcy 2003.

14 „Der Untergang”, polski tytuł „Upadek”, reżysiera Oliver Hirchbiegel, Niemcy 2004.

15 „Der Tunnel”, polski tytuł „Tunel ku wolności”, reżyseria Roland Suso Richter, Niemcy 2001.
} 
o losach mieszkańców Berlina Wschodniego, którzy chcą przedostać się na zachodnią stronę miasta. Temat zniszczenia zabytkowego Drezna miał się stać największym wyzwaniem dla twórcy oraz, jak sam przyznaje, najważniejszym filmem w jego karierze ${ }^{16}$. Realizacja „Drezna” kosztowała ok. 10 mln euro, budżet ten został w całości pokryty przez telewizję ZDF, co sprawiło, iż obraz Richtera stał się najdroższą niemieckojęzyczną produkcją filmową. W roku swojej premiery „Drezno" zostało uhonorowane Niemiecką Nagrodą Telewizyjną, a rok później najważniejszą krajową nagrodą publiczności - Jupiterem. Większość krytyków czołowych tytułów prasowych w Niemczech jednogłośnie doceniła profesjonalizm oraz rozmach, jakim cechuje się film. Interesującymi zabiegami, jaki wykorzystali twórcy było zmontowanie archiwalnych zdjęć z lutego $1945 \mathrm{r}$. z kadrami filmowymi, co sprawia wrażenie autentyczności przekazu. Na wiarygodność i wielostronność obrazu niewątpliwie wpływają także sceny rozgrywające się w kwaterze głównej RAFu, w której dochodzi niekiedy do polemiki obecnych w niej dowódców. Co więcej, przy realizacji dzieła użyto komputerowych symulacji umożliwiających widzowi "znalezienie się" w kokpicie bombowca w momencie nalotu nad miasto. Nicolaus von Festenberg, krytyk filmowy piszący na łamach tygodnika „Der Spiegel”, zachwalał producenta „Drezna”, Nico Hoffmanna i jego hollywoodzką formę: „Po «Luftbrücke» i «Die Sturmflut» producentowi Nico Hoffmannowi udaje się za sprawą «Drezna» przebłysk geniuszu - Sensownie, z hollywoodzką perfekcją i poruszająco przenieść piekło z $1945 \mathrm{r}$. na ekran telewizyjny"17. Wymienione przez recenzenta tytuły były nota bene wcześniejszymi superprodukcjami poprzedzającymi powstanie „Drezna”. Efektowny, brawurowo nakręcony film wojenny idealnie wpisał się w kontynuację nurtu dzieł o wydarzeniach przełomowych, dotykających znaczne rzesze ludzi.

Inni recenzenci obrazu Richtera zwracali szczególną uwagę na kluczową scenę bombardowania i zniszczenia miasta, która rzeczywiście robi niesamowite wrażenie: na niemal pół godziny milkną wszelkie dialogi, jeśli słychać ludzkie głosy to jedynie pojedyncze słowa bądź okrzyki. Widz jest natomiast bombardowany obrazami walących się budynków, niekończącej się pożogi, ucieczki przez piwnice, rozszarpywanych ciał, konających rannych, matki pchającej płonący wózek dziecięcy, modlących się starców. Kiedy następuje cisza - jest ona złowróżbna, oznacza bowiem piwnicę pełną ludzi, którzy zmarli wskutek zaczadzenia albo śmierć po strzałach miłosierdzia, jakie oddał zrozpaczony żołnierz proszącym go o to staruszkom.

${ }^{16}$ K. O. Derks, Teleschau, wywiad z Rolandem Suso Richterem, dostępne przez: http:// www.cineastentreff.de/content/view/1-3-165572-1/1959/186, data dostępu: 2.12.2012.

${ }_{17}$ Nicolaus von Festenberg, Von der Couch in die Hölle, Der Spiegel 9/2006. Tłum. wł. 
Twórcy filmu starali się niemniej jednak być obiektywni, wplatając w dialogi głównych bohaterów krótką dyskusję na temat wojny. W jednej ze scen rozgoryczona Anna pyta Roberta: "Jak to jest bombardować kobiety i dzieci?”, na co Robert odpowiada: „Zapytaj Luftwaffe. Zapomniałaś, kto wywołał wojnę?". W innej scenie Robert wyraża swoją dezaprobatę wobec faktu, iż Anna akceptuje system polityczny, w którym żyje, mówiąc: „Wiesz, co jest gorsze od niewoli? Być w niewoli i wmawiać sobie, że jest się szczęśliwym". Na sam koniec natomiast twórcy przenoszą nas do roku 2005, gdy zakończono odbudowę jednego z najważniejszych symboli miasta - katedry Frauenkirche i mowy prezydenta Horsta Köhlera pokoju w Europie i na całym świecie. Zabieg ten podkreśla znaczenie wydarzeń z lutego 1945 r., które trwale wpisały się w pamięć zbiorową nie tylko mieszkańców stolicy Saksonii, ale całego narodu niemieckiego.

Nie wszyscy byli jednak zachwyceni historyzmem w wersji Rolanda Suso Richtera. Krytyczka Die Zeit, Evelyn Finger, w swojej recenzji zatytułowanej „Der englische Pilot"18 wytyka twórcom sztuczność zachowań bohaterów, która według niej, doprowadza do niesłusznej gloryfikacji ludności niemieckiej i wypaczenia całości obrazu historycznego: „Niemcy zachowują się niesamowicie bohatersko. Narzeczony Anny solidaryzuje się ze swoim rywalem. Płaczący żołnierz oddaje umierającym strzał miłosierdzia, wychudły chłopiec dzieli swoją ostatnią kromkę chleba z siedzącą samotnie na ruinach dziewczynką. Tak wygląda autogloryfikacja w wielkim, telewizyjnym stylu. »Front narodowy - uważał Goebbels - jest z żelaza hartowanego przez uderzenia«. W »Dreźnie« Niemcy okazują się niemal tak heroiczni, jak oczekiwał tego minister propagandy"19. Komentarz Evelyn Finger wydaje się ciekawym głosem w dyskusji nad spójnością i realnością $\mathrm{w}$ przedstawieniach niemieckich ofiar wojny, która uwidoczniła się w opiniach dotyczących pozostałych tytułów.

Drugi z wybranych filmów nie posiada oryginalnego scenariusza, lecz stanowi ekranizację głośnej książki „Anonyma - eine Frau in Berlin” anonimowej autorki wydanej (po raz drugi) w $2003 \mathrm{r}$. Wspomnienia Berlina z przełomu kwietnia i maja $1945 \mathrm{r}$. anonimowej kobiety po raz pierwszy ukazały się w niemieckich księgarniach w roku 1959, wówczas jednakże spotkały się one z wyjątkowo chłodną recepcją - autorce zarzucano m.in. oczernianie wizerunku Niemek - i niebawem zniknęły z księgarskich półek. Po odkryciu tożsamości anonimy książkę wydano po raz drugi, co okazało się wielkim marketingowym sukcesem. Drugie wydanie szybko trafiło na listę bestsellerów w RFN i doczekało się tłumaczeń w wielu

18 „Der englische Pilot” - „Angielski pilot”. Tytuł recenzji być może powstał w wyniku parafrazy tytułu filmu Anthony'ego Minghelli „Angielski pacjent” z roku 1996.

19 Evelyn Finger, Der englische Pilot, Die Zeit, 02.03.2006 Nr 10. Tłum. wł. 
obcych językach, w tym także polskim. Dlatego też pomysł przeniesienia książki na ekran filmowy nie stanowił dużego zaskoczenia. Reżyserii "Anonymy" podjął się Max Färberböck, który w 1999 r. zadebiutował melodramatem wojennym „Aimee i Jaguar”. W realizacji „Anonymy” pojawiły się ponadto polskie akcenty - za scenerię wojennego Berlina posłużyły dwa polskie miasta: Legnica i Wrocław, zaś muzykę skomponował Zbigniew Preisner.

Podobnie jak w przypadku „Drezna”, krytykom „Kobiety w Berlinie” przypadł do gustu efektowny sposób kręcenia filmu. Sceną otwierającą jest wkroczenie Armii Czerwonej do Berlina i walki w kamienicy - scena jak z klasycznego filmu wojennego. Zdjęcia są niezwykle ostre, scenografia przekonywająca, a preisnerowska ścieżka dźwiękowa wyjątkowo ekspresyjna. Pochwały recenzentów zebrała także Nina Hoss, odtwórczyni głównej roli. Narratorka książki opisywała upadek Rzeszy chłodno i epigramatycznie. $W$ jej zdaniach emocje były ledwo wyczuwalne. To, co w książkowej Anonimie osiągnięte zostało poprzez oszczędność słowną, w filmie jest oparte na niemal całkowitym braku mimiki Niny Hoss i jej monotonnym głosie. „Hoss odgrywa ten upadek z dokładnie tą mieszanką nieprzystępnego chłodu i wrażliwej głębi, która do perfekcji została opanowana przez niemieckie kino" - chwalił aktorkę dziennik Süddeutsche Zeitung ${ }^{20}$.

Na tym jednak ciepłe słowa pod adresem twórców filmu przeważnie się kończyły. Krytycy niemal wszystkich wiodących tytułów popularnej prasy niemieckiej potępiali znaczne odstępstwa filmowej adaptacji od anonimowego dziennika. Warto pokrótce zwrócić uwagę na dwie najbardziej rzucające się w oczy różnice:

Pierwszą z nich jest kreowanie nastroju końca wojny i wkroczenia, a później omnipotencji Rosjan. W zapiskach Anonymy ich przyjście poprzedzone jest wielką niepewnością. Co z nami będzie? To pytanie mniej lub bardziej bezpośrednio pojawia się na ustach wszystkich bohaterów. W codziennych rozmowach pojawiają się wzmagające lęk pogłoski o okrucieństwie i bezwzględności Rosjan. Słabe, dochodzące z daleka odgłosy artylerii zwiastują nadejście końca, nie obwieszczając jednak dokładnego jego terminu. Na jeden z pobliskich domów spada bomba. Jest krzątanina, gorączkowe poszukiwanie żywności, ciemność, zamieszanie, plądrowanie. Kiedy wreszcie pojawia się Armia Czerwona, jesteśmy na trzydziestej ósmej stronie zapisków. Autorka notuje: „Zaczęło się ciszą. Wokół cicha noc". Dopiero nieco później rozlega się świst kul i to na krótko, zaraz potem pojawia się niekończący się orszak ludzi ze zwierzętami. W filmowej wersji "Anonymy" akcja nie zaczyna się ciszą - zamiast niej jest brawurowo nakręcona scena ataku Rosjan na pojedynczo broniących się Niemców

${ }^{20}$ A. Kreye, Männer, von Natur aus feige, Süddeutsche Zeitung, 22.10.2008. Tłum. wł. 
w kamienicy. Jest zatem wielka strzelanina, pościg za partyzantami w budynku, giną ludzie, słychać krzyki. Niedługo potem słyszymy ekspresyjną muzykę Zbigniewa Preisnera. Zimne dźwięki fortepianu podkreślają dramatyzm sytuacji. Twórcy filmu całkowicie zrezygnowali ze stopniowego budowania napięcia, zastępując je scenami prosto $\mathrm{z}$ hollywoodzkiego filmu wojennego.

Z każdą sceną ów dysonans się nasila. Zapiski anonimowej berlinki stanowią nieoceniony obraz rzeczywistości upadłej stolicy Rzeszy i ilustrację zachowań jej społeczności, czytelnik jest zatem świadkiem życia, a właściwie egzystencji $\mathrm{w}$ mieście ruin, bez wody, bez prądu, z bardzo ograniczoną ilością żywności, o którą i tak zresztą trzeba walczyć, za to z ogromnymi pokładami strachu i niepewności. W sobotę 19 maja $1945 \mathrm{r}$. autorka pisze na przykład: „Żyjemy bez gazet, bez odmierzania godzin, niczym kwiaty orientujemy się według słońca. Kiedy przyniosłam wody i nazbierałam drewna, poszłam na zakupy. Jako pierwsza dostałam na nowe kartki kaszę, wieprzowinę i cukier. W kaszy pełno orkiszu, cukier skawalony z powodu wilgoci, mięso sztywne od soli, jednak to pożywienie. Jesteśmy zadowoleni" ${ }^{\prime 2}$. Głód w zapiskach Anonymy jest podstawowym wyznacznikiem niepewności o jutro i stale powracającym motywem, który nawet kończy zapiski. Obraz wychudzonej chabety przed domem i proste pytanie dziecka, czy koń jest jadalny, stanowi kwintesencję każdego pisanego źródła z okresu wojny. Innym dającym się we znaki problemem jest po części wynikające z głodu ogólne wyczerpanie fizyczne. W rządzonym przez Rosjan mieście kobieta musi pokonywać duże odległości pieszo, pod koniec maja musi dodatkowo godzinami pracować w naprędce zorganizowanej pralni, w efekcie czego czuje się przemęczona. Takiego obrazu rzeczywistości w filmie Färberböcka nie ma. Scenografia w zasadzie ogranicza się do ciemnych wnętrz ocalałych budynków rzadko wychodząc na ulicę, nie mówiąc o penetracji dalszych zakątków Berlina. Widoczny jest brak konsekwencji w stosowaniu pierwszoosobowej narracji filmowej - fragmenty dziennika anonimy pojawiają się jedynie sporadycznie. Kiedy to, co najbardziej wstydliwe i poniżające, czyli gwałt, było w książce przykrywane zasłoną milczenia, w filmie pokazane jest w sposób bezpośredni. Przede wszystkim zaś problemy takie jak głód, brak wody, noszenie ciężkich wiader i wyczerpanie fizyczne właściwie nie istnieją. Co stanowi zatem rdzeń filmowej fabuły?

W tym momencie dochodzimy do różnicy najbardziej wymownej i najostrzej potraktowanej przez krytykę, a mianowicie wątku miłosnego między główną bohaterką a radzieckim majorem. Książkowa Anonyma gościła u siebie, a także akceptowała seksualną relację z majorem, chcąc

${ }^{21}$ Anonyma, Kobieta w Berlinie. Zapiski z 1945 r., Warszawa 2009, s. 151. 
uniknąć konfrontacji z innymi żołnierzami radzieckimi, którzy ją nachodzili w jednym, konkretnym celu. Metoda ta okazała się skuteczna w zamian za kilkukrotne oddanie się majorowi kobieta uzyskała ochronę przed dużo brutalniejszymi gwałcicielami. Major nie jest jednak w dzienniku postacią bardzo znacząca czy wręcz bohaterem drugoplanowym; w książce bohaterów takich właściwie nie ma. W filmie natomiast postać majora urasta do pierwszoplanowej roli męskiej, a łącząca go relacja z kobietą to po prostu miłość. Warto przytoczyć kilka komentarzy niemieckiej prasy. Chyba najłagodniejsza w słowach była recenzentka Sterna: „Film Maxa Färberböcka czyni z wymuszonej wspólnoty ckliwą historię miłosną, chociaż w dzienniku nie ma o tym mowy"22. We fragmencie nieco ostrzejszej recenzji Spiegla czytamy: „Zupełnie inaczej niż w książce, gdzie relacja [...] rozwija się chłodno, w filmie jest ona rozdmuchana do niemal kiczowatej tragedii miłosnej"23. Na przemalowywanie historii, które jest efektem melodramatyzacji historii, zwrócił natomiast uwagę krytyk Frankfurter Allgemeine Zeitung: "«Anonyma» to straszny film - nie przez to, co opowiada, lecz przez sposób, w który kompromituje swoje własne założenia [...]. Wstyd, poczucie winy i cielesne szczęście to dla niego [reżysera - przyp. autora] za mało - to przecież musi być miłość, kiedy kobieta $\mathrm{W}$ niebieskim płaszczu przyjmuje majora. $\mathrm{W}$ ten sposób przemalowuje on historyczne świadectwo w cukierkową barwę melodramatu"24.

Podobnie jak w przypadku „Drezna” także w "Anonymie” posłużono się prostą i sprawdzoną w Hollywood konwencją melodramatu. O ile jednak "Drezno" Richtera nakręcone zostało w oparciu o scenariusz oryginalny, bazujący na fikcji, o tyle "Anonyma” to scenariusz adaptowany, pierwowzorem zaś są zapiski wygłodzonej i zmęczonej kobiety w Berlinie, która swych relacji z radzieckim majorem nie traktowała jako miłości, zatem wprowadzenie takiej a nie innej konwencji przez Fäberböcka trudno zrozumieć i zaakceptować.

W tym samym roku co „Anonyma” powstał film Josepha Vilsmayera "Gustloff”. Nazwany w niemieckich mediach, ze względu na podział na dwa trzygodzinne odcinki, dwuczęściowcem (Zweiteiler) potwierdził tendencję przejmowania hollywoodzkich wzorców przez niemieckie dramaty wojenne. „Gustloff” nie był pierwszym dramatem wojennym w karierze Vilsmayera. 15 lat wcześniej ukazał on najważniejszą klęskę wojenną Niemiec, która odmieniła losy wojny. Film zatytułowany po prostu „Stalingrad" był klasycznym filmem wojennym, realistycznym, sugestywnym, obrazującym wojnę najpierw jako niewinne potyczki, które stopniowo

\footnotetext{
${ }^{22}$ A. Lösel, Und dann bedienten sich die beiden, Stern.de, 2.11.2008. Tłum. wł.

${ }^{23}$ A. Kilb, Kitsch und Vergewaltigung: "Anonyma”, FAZ, 13.11.2012.

${ }^{24}$ Ibidem.
} 
przeobrażają się w wyniszczający żywioł. Zrealizowany przy współpracy z telewizją ZDF z imponującym budżetem ponad 10 mln euro "Gustloff" okazał się komercyjnym strzałem w dziesiątkę, przyciągając w dniu swojej telewizyjnej premiery $8,5 \mathrm{mln}$ widzów. Drugi program telewizji zadbał również o to, by widzowie nie odchodzili od odbiorników zbyt szybko tuż po obejrzeniu filmu - bezpośrednio po nim wyświetlony został dokument z serii "Zeitgeschichte" o zatopieniu Gustloffa, który obejrzało ponad 5 mln widzów ${ }^{25}$. Pod wieloma względami Gustloff przypomina najsłynniejszy film o katastrofie morskiej, jakim był „Titanic” Jamesa Camerona z 1997 r., także, jeżeli porówna się warstwę fabularną i sposób konstruowania narracji. Podobnie jak w "Titanicu” znaczna część akcji „Gustloffa” rozgrywa się przed wypłynięciem statku na morze, który stoi w porcie Gotenhafen przez niemal całą pierwszą część filmu. O ile jednak Titanic wypływał w czasie pokoju i był entuzjastycznie żegnany przez ludność Southampton, Gustloff opuszczał Gotenhafen w czasie wojny, w obliczu zbliżającej się ofensywy Armii Czerwonej, a jego wypłynięciu towarzyszyły dantejskie sceny. Zamiast machających do siebie uśmiechniętych rodzin mamy obraz ludzi tratujących się nawzajem, pragnących za wszelką cenę dostać się na pokład Gustloffa, widząc w statku ostatnią deskę ratunku przez Rosjanami. Gdy Gustloff wreszcie odpływa, pasażerów stopniowo ogarnia spokój. Choć kamera obejmuje swym obiektywem setki tłoczących się ludzi, na pierwszy plan narracji ze zrozumiałych względów wysuwa się dwoje bohaterów: kapitan w cywilu Helmut Kehding, który sprzeciwia się absurdalnym rozkazom innych kapitanów (postać fikcyjna) oraz jego wielka miłość, udzielająca się w Kriegsmarine Erika Galetschky. I w przeciwieństwie do „Titanica” zarówno ona, jak i on, przeżywają katastrofę i wychodzą na suchy ląd.

Obraz Vilsmayera spotkał się nie tylko z ogromnym zainteresowaniem widzów, ale również z przychylnym nastawieniem części krytyki. Nawet recenzentka Die Zeit, której, jak cytowano wcześniej, wizja historyczna zaprezentowana w "Dreźnie” wyjątkowo nie przypadła do gustu, nie kryła wyrazów zachwytu nad „Gustloffem”, pisząc: „Nareszcie dobry film telewizyjny o II wojnie światowej [...]. Gustloffa Josepha Vilsmayera można nazwać cudem telewizji. Tutaj bowiem opowiada się o końcu wojny w innym, nieheroicznym stylu, który twórcy filmowi tak pielęgnowali w ostatnich latach" ${ }^{26}$. Mając w pamięci obraz postaci w „Dreźnie”, które w czasie bombardowania zachowywali się nadspodziewanie heroicznie, postaci w "Gustloffie" są przedstawione całkowicie neutralnie. W obliczu katastrofy statku i powszechnej śmierci z ust bohaterów nie padają

${ }^{25}$ Dane ze strony Kinozeit, http://www.kino-zeit.de/news/8-45-millionen-zuschauerfur-die-gustloff, ostatni dostęp: 6.01.2013.

${ }^{26}$ E. Finger, Geschichte, mal ehrlich, Die Zeit, 28.02.2008, nr 10. Tłum. wł. 
patetyczne słowa, nikt nie dokonuje niesamowitych czynów, lecz stara się zachować własne życie. Nawet wątek melodramatyczny rozwijający się między Eriką a Kehlingiem pozostaje stonowany i stanowi jedynie tło.

Nie wszyscy jednak podzielali entuzjazm recenzentki Die Zeit. Stern zarzucał filmowi Vilsmayera schematyzm: „Wszystko w tym filmie jest przewidywalne. Ludzi porywa jedynie woda, a nie filmowa narracja [...]. Fabuła jest schematyczna, bohaterowie pochodzą z drzeworytu. ZDF nieustannie powtarza, że zatonięcie Gustloffa było rzekomo większą katastrofą morską niż ta Titanica. Film taki nie jest"27. "Gustloff" został zauważony także w polskich mediach, spośród których Gazeta Wyborcza podziela zdanie Sterna: „Choć w tle rozgrywa się tragedia, widz może liczyć na happy end. «Gustloff» zatonie, zginą tysiące ludzi, ale może dobry kapitan i jego ukochana ocaleją? [...]. Żeby jednak nie komplikować sprawy, nie tłumaczy się widzowi, że port Gotenhafen, z którego wypływa «Gustloff», to polska Gdynia. Polski nie ma w «Gustloffie» wcale"28. W swej recenzji Bartosz Wieliński dotyka bardzo istotnej kwestii, jaką jest subiektywna wizja historii zaprezentowana przez Vilsmayera. Mimo iż statek odpływa z Gotenhafen, które jeszcze pięć lat wcześniej nosiło nazwę Gdynia i było (w przeciwieństwie do umiędzynarodowionego przez Ligę Narodów Gdańska) całkowicie polskim miastem, o geograficznym położeniu portu i jego historii (czy historii sprzed 1945 r.) nie ma w ogóle mowy.

Do dalej idących wniosków doszła krytyczka Die Zeit, która jako jedna z nielicznych filmoznawców, a nie historyków, zwróciła uwagę na osadzenie fabuły właśnie w końcowym okresie wojny: „Film Gustloff sprowadza narodowy socjalizm z powrotem do poziomu jednostki, przez co zostaje daleko w tyle za stanem badań ostatnich 15 lat. Sam temat zresztą nie jest nowy. Już w roku 1959 nakręcono film o zatonięciu Wilhelma Gustloffa («Nacht fiel über Gotenhafen», reż. Franz Wisbar). Słusznie krytykuje Harald Welzer to, że w filmach takich jak «Der Untergang» stale inscenizowany jest koniec narodowego socjalizmu, a nie jego początek, i to jako tragedia [...]. W roku 2008 zwrot «pokolenie sprawców» wyszedł z mody. Wprawdzie nie ośmiela się jeszcze mówić o «pokoleniu ofiar», jednak poprzez milczący konsensus zgodzono się na sformułowanie «pokolenie świadków tamtych czasów»"29. Przed ustosunkowaniem się do ostatniego fragmentu wypowiedzi, warto zwrócić uwagę na symboliczną datę zatonięcia Gustloffa, czyli 30 stycznia, która mogła się przecież stać pretekstem do zastosowania retrospekcji i przesunięcia na chwilę linii fabularnej w przeszłość. Symbolika, która stanowiła oś opowiadania Grassa, łącząc

${ }^{27}$ B. Gäbler, „,Gustloff" - ein Filmgenre säuft ab, Stern.de, 4.03.2008. Tłum. wł.

${ }^{28}$ B. Wieliński, Jak „Gustloff” został niemieckim „Titanikiem”, Gazeta Wyborcza, 30.01.2012.

${ }^{29}$ T. Dückers, Alles nur Opfer, Zeit Online, 7.03.2008. Tłum. wł. 
trzy płaszczyzny czasowe w jednym dziele, nie została wykorzystana przez Vilsmayera, mimo iż jego obraz trwał niemal sześć godzin. Bez tak zwanego drugiego dna, bez odniesień do przeszłości, film po prostu przedstawia losy tysięcy ludzi, którzy w pierw tłoczą się wchodząc na pokład statku, by potem zginąć, rozstrzaskując się o różne przedmioty bądź zamarzając w lodowatej wodzie, co jest możliwe dzięki starannej scenografii, dużej liczbie statystów, czyli właściwie dużemu budżetowi niemal na hollywoodzką miarę.

Konwergencję wielkich produkcji kina niemieckiego z Hollywood można oceniać dwojako: $\mathrm{z}$ jednej strony jest to kino nieskomplikowane, zrozumiałe dla przeciętnego widza, który nie pragnie odnajdywać w filmie historycznym wieloznaczności, czyli tzw. drugiego dna. Jest to bowiem tak naprawdę kino rozrywkowe, zrealizowane przy dużym budżecie, z ogromnym rozmachem, po to aby przyciągnąć jak najliczniejsze rzesze widzów. Także pod względem narracji mamy do czynienia z amerykanizacją dzieła, a więc z typowym (w przypadku niektórych filmów) hollywoodzkim happy endem, melodramatyzmem stanowiącym główny wątek historii oraz klasycznym typem narracji, w którym widz ogląda wydarzenia oczami głównego bohatera (bohaterów) utożsamiając się z nim i nie kwestionując tego obrazu. W przypadku kina wojennego rozwiązanie to wydaje się najprostsze zarówno w realizacji, jak i odbiorze, choć nie jest obowiązkowe ${ }^{30}$.

$\mathrm{Z}$ drugiej strony wobec omawianych filmów niemieckich można postawić te same zarzuty, które niektórzy krytycy stawiali niegdyś „Liście Schindlera" Stevena Spielberga. Miriam Bratu Hansen, wybitna ekspertka w zakresie filmoznawstwa i kultury masowej, analizując najsłynniejszy fabularny film poświęcony szoah, podkreślając najpierw ogromną falę pozytywnej krytyki, jaka przetoczyła się przez media (a także politykę) po jego premierze w 1993 r., zwróciła uwagę kontrowersyjne cechy narracji dzieła $^{31}$. W „Liście Schindlera” na pierwszy plan w warstwie fabularnej wysuwa się nie śmierć setek, czy wręcz tysięcy ludzkich istnień, lecz przeżycie jednostek, co podkreślone jest w końcowych scenach filmu. Podobny zabieg widoczny jest w "Dreźnie” - Annie i Robertowi udaje się szczęśliwie przetrwać bombardowanie miasta, wyznają oni sobie nawet miłość - a także w "Gustloffie": Kehding i Erika znajdują się w gronie nielicznych szczęśliwców ocalonych z tonącego statku.

${ }^{30}$ Przykładem niech będą choćby filmy: "Courage under fire" Edwarda Zwicka (polski tytuł "Szalona odwaga”), USA 1996 oraz "Casualties of war" Briana de Palmy (polski tytuł "Ofiary wojny”), USA 1989.

${ }^{31}$ M. B. Hansen, Schindler's List Is Not Shoah: The Second Commandment, Popular Modernism, and Public Memory [w:] M. Landy (red.), The Historical Film: History and Memory in Media, New Brunswick 2001, s. 292-313. 
Inny, dużo poważniejszy i trudniejszy do rozpatrzenia zarzut, jaki części krytyki stawiała wobec dzieła Spielberga, wydaje się adekwatny również w stosunku do rozpatrywanych filmów niemieckich. Otóż jak twierdził sam Steven Spielberg, "Lista Schindlera” nie miała opowiadać pojedynczej historii związanej z szoah, lecz być filmem o samym szoah, ukazując zagładę jako zjawisko w sposób reprezentatywny. Część krytyków poszła dalej tym tropem zadając w konkluzji pytanie, czy obraz goja-zbawiciela i cudu przeżycia nie wypacza całości obrazu, czy mówiąc wprost - prawdy historycznej ${ }^{32}$. Dochodząc wreszcie do kwestii najistotniejszej, czyli pytania, czy omawiane filmy niemieckie dokonują manipulacji albo reinterpretacji historii, warto mieć na uwadze ww. spostrzeżenia. Czy „Drezno" nie jest filmem reprezentatywnie traktującym o zniszczeniu zabytkowego miasta? Czy "Gustloff" nie jest reprezentatywnym filmem o śmierci tysięcy cywili w lodowatych wodach Bałtyku? W przypadku dziennika "Anonymy” trudno stosować taką kategorię, gdyż dziennik z samej zasady jest subiektywną formą wypowiedzi i trudno w nim o szeroki, wieloaspektowy obraz rzeczywistości, jednakże film „Kobieta w Berlinie" stanowi tak naprawdę jedynie luźną jego adaptację (choćby poprzez drastyczne ograniczenie narracji pierwszoosobowej). Czy filmowa "Anonyma" nie jest zatem reprezentatywnym dziełem o masowych gwałtach dokonywanych przez czerwonoarmistów?

Trudno na powyższe pytania udzielić jednoznacznej odpowiedzi. Przede wszystkim filmy takie jak "Gustloff”, „Anonyma”, „Drezno", „Ucieczka” ze zrozumiałych powodów nie gloryfikują III Rzeszy ani nie kwestionują niemieckiej odpowiedzialności za wywołanie wojny. Czyny głównych decydentów III Rzeszy w ostatnich tygodniach wojny są osądzane surowo jako ślepa droga do destrukcji i cierpienia ludności niemieckiej. Nawet w najbardziej kontrowersyjnym „Upadku” Hirschbiegela walka nie ma sensu - fanatyczny upór bezsilnego Hitlera i niemożliwość zaakceptowania kapitulacji powodują niepotrzebną śmierć kolejnych istnień. $\mathrm{Z}$ drugiej strony wszystkie te filmy mają jeden mianownik - ich akcja rozgrywa się w czasie ostatnich dni bądź tygodni wojny, żaden z nich choćby w retrospekcjach nie przywołuje wydarzeń wcześniejszych, nie mówiąc o okresie 1933-39. Nawet "Gustloff” Vilsmayera, pomimo symbolicznych przesłanek do odwołania się do przeszłości, jak słusznie zauważa recenzentka Die Zeit, koncentruje się jedynie na „tu i teraz". Jest to tym bardziej osobliwe, że retrospekcja (lub reminiscencja) to środek artystyczny, który doskonale odnajduje się $\mathrm{w}$ kinie, także wojennym i katastroficznym. Innym ze środków, o który mógłby się pokusić każdy z reżyserów wspomnianych filmów, jest montaż synchroniczny polegający na zestawieniu

\footnotetext{
${ }^{32}$ Ibidem, s. 297.
} 
obok siebie równolegle toczących się wydarzeń. Zabieg ten perfekcyjnie zastosował Rainer Werner Fassbinder w „Lili Marleen” - sceny, w których główna bohaterka śpiewa tytułową piosenkę zostają w pewnym momencie przemieszane $\mathrm{z}$ przerażającymi scenami z frontu.

Tematyka najnowszej kinematografii wojennej w Niemczech i motyw cierpiącej ludności niemieckiej z pewnością zasługuje na dalsze badania szczególnie w kontekście społecznego zjawiska, jakim jest trwające od lat „przezwyciężanie przeszłości”. Z racji wysokiego poziomu komercyjności filmy te mogą znacząco wpływać na kształtowanie się świadomości historycznej Niemców, zwłaszcza tych, którzy II wojnę światową znają jedynie ze źródeł sekundarnych. Ponadto stanowią kontynuację procesu, którego istnienie podkreślają czołowi badacze polityki historycznej i pamięci kulturowej, a które zostało zapoczątkowane w literaturze i które przeniosło się na ekrany kinowe. Omówione w tym artykule tytuły z oczywistych przyczyn nie wyczerpują tej tematyki, co więcej, nic nie wskazuje na to, by były to ostatnie filmy Niemców o Niemcach w czasie ostatniej wojny światowej.

\section{Zusammenfassung}

Der Artikel bespricht drei ausgewählten Filmtitel: „Die Gustloff“, „Dresden“ und „Anonyma - eine Frau in Berlin“, was selbstredend das umfangreiche Thema nicht erschöpft. Im Text werden die Hauptpunkte der Erzählung und anschließend die Rezeption anhand unterschiedlichen Presserezensionen dargestellt. Darüber hinaus wird im Artikel eine offene Frage aufgeworfen, inwieweit die neuesten Filme über deutsche Kriegsopfer das öffentliche und kollektive Gedächtnis beeinflussen sowie inwiefern das doppelte Täter-Opfer-Gedächtnis in der deutschen Kultur ausbalanciert bleibt. 